\title{
Performance Evaluation of Anaerobic Biodegradation of Synthetic Phenolic Waste Water in Single Stage Fixed Bed Bio- Reactor
}

\author{
Dr. Mishu Singh \\ Head, Department of Chemistry, Maharana Pratap Govt. P.G. College, Hardoi
}

\begin{abstract}
Biological treatment systems are supposed to be advanced in the sense that they are more effective and involve a greater degree of stabilization of waste. The treatment of toxic and inhibitory phenolic compounds using biological techniques have been pursued vigorously as a promising and widely accepted treatment process due to its ease of handling and properly operated to prevent the production of secondary pollutants. Upflow anaerobic bioreactors (UAFB) have been widely used for the treatment of high organic load industrial wastewater. The treatment of synthetic phenolic wastewater by a single stage anaerobic fixed bed bioreactor with granite stones packing at a temperature of $30^{\circ} \mathrm{C}, 35^{\circ} \mathrm{C}, 40^{\circ} \mathrm{C}$ and $45^{\circ} \mathrm{C}$ was studied. A recirculated single stage up-flow anaerobic bioreactor was operated at all the above-given temperatures with initial BOD $1462 \mathrm{mg} / \mathrm{l}$ and initial COD $5720 \mathrm{mg} / \mathrm{l}$ for a digestion period of 25 days with a working volume of $1000 \mathrm{ml}$. The performance of the reactor was monitored after every five days and analyzed in terms percentage $C O D, B O D, T S, T D S, V S$ removal and biogas production. The removal efficiency of BOD, COD, TS, TDS and VS could reach to a maximum value of $63.20 \%, 61.24 \%, 44.88 \%, 47.67 \%$ and $53.12 \%$ respectively. The result showed that the maximum biogas production in the reactor reached 0.0077 liters /liter /day at a temperature of $40^{\circ} \mathrm{C}$.
\end{abstract}

Keywords: Phenol, anaerobic, fixed bed bioreactor, wastewater, up flow anaerobic sludge blanket.

Abbreviations: BOD -Biochemical Oxygen Demand, COD - Chemical Oxygen Demand, TDS - Total Dissolved Solids, VS - Volatile Solids, UAFB - Upflow Anaerobic Fixed Bed Bioreactor

\section{Introduction}

It been reviewed that aromatic compounds are plentiful in the environment (Lettinga et al., 2001, Colleran et al., 2002, G. Collins, 2005). One group of these products is phenolic compounds. It has been demonstrated that phenol can be degraded, under anaerobic conditions, to methane and carbon dioxide as reviewed in several reports (Guieysse. et al., 2001, Li and Fang, 1996. However, at some concentrations, phenol may promote inhibitory effects in methanogenic bacteria, diminishing methane production and carbon degradation (Rebaca and Gerbens, 1999). Therefore, phenolic compounds are problematic for the anaerobic treatment of wastewater. One report (Hernandez, 2003) sets that various alternatives (dilution, ozonation, UV$\mathrm{H}_{2} \mathrm{O}_{2}$ ) been proposed to eliminate toxicity and improve phenol's anaerobic biodegradation. Previous works on phenol anaerobic biodegradation have been carried out in batch (Banks and Wang, 1999) and continuous operation: fluidized bed (Mc Hugh et al., 2004.), UASB (Chang et al., 1995) and expanded bed reactor (Collins et al., 2005)

Treatment of phenol and cresols in upflow anaerobic sludge blanket (UASBR) has been reviewed by Veeresh et al. (2005). It has been reported that the anaerobic bacteria have the capability to degrade phenol as a sole substrate (Fang et al. 1996; Chang et al. 1995; Tay et al. 2000) and use of a co-substrate is not a prerequisite. However, the presence of a co-substrate retards/prevents the toxic effects of phenols during shocks helps in complete biodegradation of phenol (Tay et al. 2001) and facilitates fast recovery of the process. Pure substrates such as glucose (Hwang and Cheng, 1991; Tay et al. 2001) and volatile fatty acids (VFA) (Kennes et.al., 1997) have been used as co-substrates in the anaerobic treatment of phenols in UASBR. The use of pure substrates restricts the practical applicability of the process. Therefore, it has been deemed necessary to assess the potentials of a readily degradable wastewater as a co-substrate in the treatment of phenolic waste. The present technical note describes the performance of a (UAFB) upflow anaerobic fixed bed bioreactor treating synthetic wastewater.

\section{Materials and Methods}

Synthetic wastewater containing phenol was produced with COD: N: P ratio of 100: 2.5: 0.5, using urea and potassium dihydrogen phosphate as a chief source of nitrogen and phosphorous respectively. The phenolic wastewater contained BOD (biochemical oxygen demand) of value 1278 $\mathrm{mg} / \mathrm{l}$ and COD (chemical oxygen demand) of value 5000 $\mathrm{mg} / \mathrm{l}$. In this study synthetic phenolic wastewater was prepared as and when required. The composition was maintained by diluting it with distilled water. To support the growth of microorganisms, nutrients like nitrogen and phosphorous were added in a ratio of COD: N: P of 50: 2.5: 1. Synthetic wastewater containing phenol was used as a sole carbon source. Urea and potassium dihydrogen phosphate were used as a chief source of $\mathrm{N}$ and $\mathrm{P}$. Besides this inorganic ion like $\mathrm{Na}^{+}, \mathrm{K}^{+}, \mathrm{Ca}^{2+}, \mathrm{Mg}^{2+}$ and $\mathrm{Fe}^{3+}$ were added in small quantities.

An anaerobic mixed culture was developed from cow dung in yeast extract media by digesting it up to two weeks at $35^{\circ} \mathrm{C}$ temperature, which was further enriched in the synthetic medium of acetic acid. Acetic acid was added to inhibit the growth of acidogenic bacteria. The methanogenic culture was enriched in the acetic medium. This culture so obtained was used as inoculums for the batch process. As 


\section{International Journal of Science and Research (IJSR) \\ ISSN (Online): 2319-7064 \\ Index Copernicus Value (2013): 6.14 | Impact Factor (2014): 5.611}

phenol is toxic to micro-organisms and is a good disinfectant, its higher concentration may prevent microbial growth in waste water may prevent microbial growth or at least make it difficult to sustain, so the mixed culture was thus developed was adapted to the phenolic wastewater. For adaptation the concentration of phenol was gradually increased from $100 \mathrm{mg} / 1$ to $1000 \mathrm{mg} / \mathrm{l}$. This experiment was carried out for 14 days at $35^{\circ} \mathrm{C}$ temperature. The biogas production was measured each day to ensure the bacterial activity. Phenolic waste water and the developed adapted mixed culture was mixed in definite proportion and was introduced into the single stage attached film fixed bed bioreactor and was allowed to ferment anaerobically for a period of 25 days at four different temperatures $30^{\circ} \mathrm{C}, 35^{\circ} \mathrm{C}$, $40^{\circ} \mathrm{C}$ and $45^{\circ} \mathrm{C}$ respectively. $100 \mathrm{ml}$ seed material was used in each digester. $\mathrm{pH}$ was adjusted by adding lime when required.

The single stage anaerobic attached film fixed bed reactor with a working volume of $1000 \mathrm{ml}$ was packed with granite a stone of size $1.0 \mathrm{~cm}$ to $1.5 \mathrm{~cm}$ in diameter.The reactor consists of a jacketed column to maintain the temperature by flowing water in the outside jacket using a thermostat water bath. The reactor was initially fed at a rate of $25 \mathrm{ml} / \mathrm{hr}$ to maintain the HRT of 24 hours. Continuous recycle of the treated effluent (phenolic wastewater) was done for the partial fluidization of the sludge by a peristaltic pump. These pumps were calibrated for different flow rates. Reactor performance was evaluated on the basis of COD, BOD, TS,
TDS, VS and biogas production at four different temperatures $30^{\circ} \mathrm{C}, 35^{\circ} \mathrm{C}, 40^{\circ} \mathrm{C}$ and $45^{\circ} \mathrm{C}$.

\section{Results and Discussions}

Phenols are known to be highly toxic to the microorganisms. After the development of methanogenic culture, $100 \mathrm{ml}$ inoculum was mixed with waste water having phenol concentration $100 \mathrm{mg} / \mathrm{l}$. After two weeks, $100 \mathrm{ml}$ inoculum was taken from this experiment and waste water with 200 $\mathrm{mg} / \mathrm{l}$ phenol concentration was inoculated. In this manner highest concentration of phenol i.e. $1000 \mathrm{mg} / \mathrm{l}$ was digested and \% COD removal of $59.33 \%$ was achieved.This can be seen in the table- 1 and fig $-\mathbf{1}$

Table 1: Percentage Phenol Removal During Adaptation of Phenolic Wastewater

\begin{tabular}{|c|c|c|c|c|}
\hline S. No & $\begin{array}{c}\text { Initial Phenol Conc. } \\
(\mathrm{mg} / \mathrm{l})\end{array}$ & $\begin{array}{c}\text { Initial COD } \\
(\mathrm{mg} / \mathrm{l})\end{array}$ & $\begin{array}{c}\text { Final COD } \\
(\mathrm{mg} / \mathrm{l})\end{array}$ & $\begin{array}{c}\% \text { COD } \\
\text { Removal }\end{array}$ \\
\hline 1. & 100 & 804 & 699 & 13.05 \\
\hline 2. & 200 & 1627 & 1363 & 16.22 \\
\hline 3. & 300 & 2082 & 1620 & 22.19 \\
\hline 4. & 400 & 2877 & 2047 & 28.84 \\
\hline 5. & 500 & 3958 & 2493 & 37.01 \\
\hline 6. & 700 & 4495 & 2425 & 46.05 \\
\hline 7. & 800 & 5746 & 2722 & 52.62 \\
\hline 8. & 1000 & 6728 & 2736 & 59.33 \\
\hline
\end{tabular}

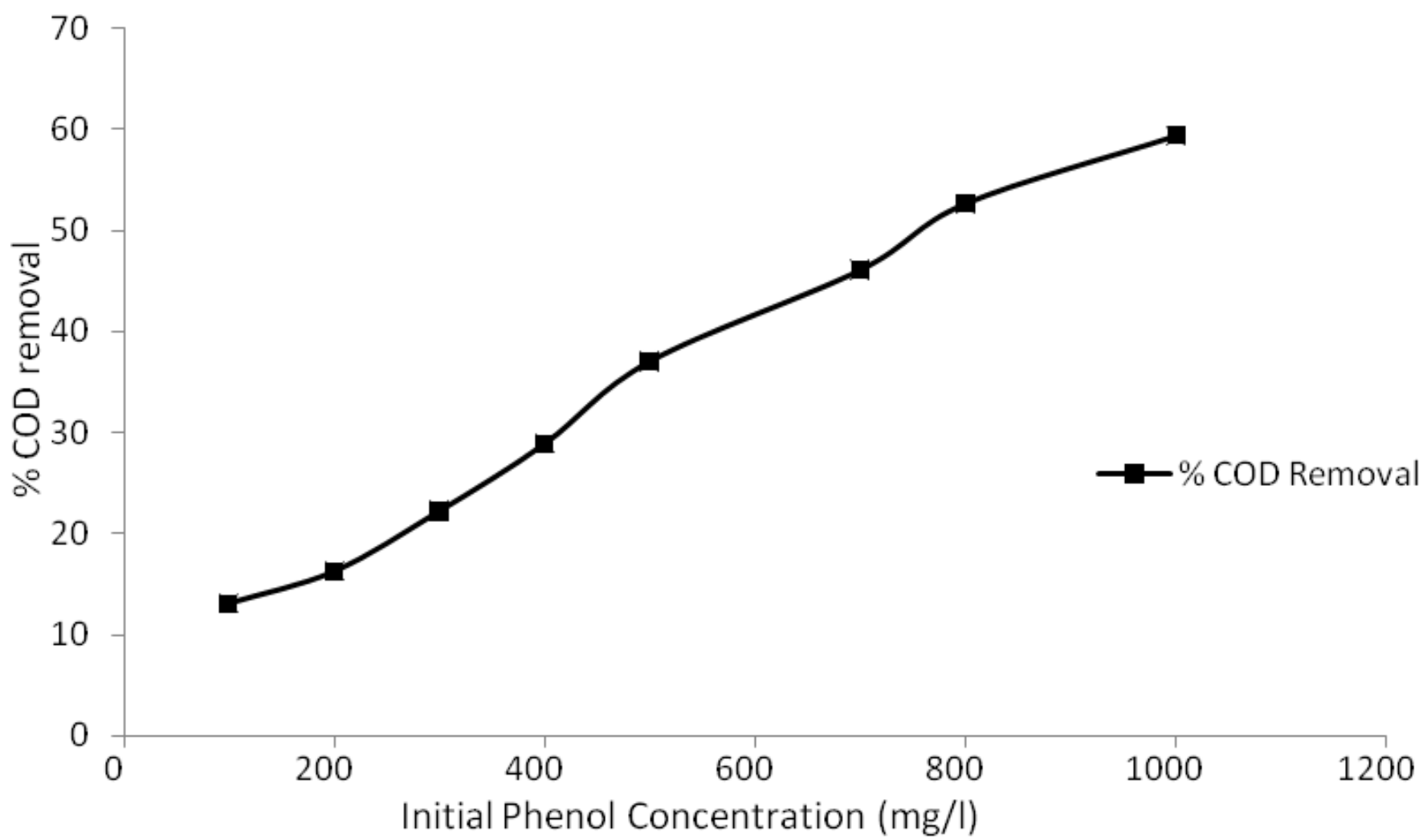

Figure 1: Percentage COD Removal during Adaptation of Phenolic Waste water

The characteristics of the treatment mixture viz. BOD, COD, TS, TDS and VS at different digestion time at four different temperatures $30^{\circ} \mathrm{C}, 35^{\circ} \mathrm{C}, 40^{\circ} \mathrm{C}$ and $45^{\circ} \mathrm{C}$ are shown in the table -2 , table- 3 , table- 4 and table- 5 respectively. Fig-2, fig3 , fig-4, fig-5 and fig- 6 represent the effect of digestion time on $\%$ BOD, $\% \mathrm{COD}, \% \mathrm{TS}, \% \mathrm{TDS}$ and $\% \mathrm{VS}$ reduction respectively.

At $30^{\circ} \mathrm{C}$ BOD and COD of the treatment, mixture ranged between $1462 \mathrm{mg} / \mathrm{l}$ to $625 \mathrm{mg} / \mathrm{l}$ and $5720 \mathrm{mg} / \mathrm{l}$ to $2882 \mathrm{mg} / \mathrm{l}$ 


\section{International Journal of Science and Research (IJSR) \\ ISSN (Online): 2319-7064}

Index Copernicus Value (2013): 6.14 | Impact Factor (2014): 5.611

respectively. The total dissolved solids ranged from 254 $\mathrm{mg} / \mathrm{l}$ to $160 \mathrm{mg} / \mathrm{l}$, total dissolved solids ranged from 172 $\mathrm{mg} / \mathrm{l}$ to $100 \mathrm{mg} / \mathrm{l}$ and volatile solids ranged from $128 \mathrm{mg} / \mathrm{l}$ to $68 \mathrm{mg} / \mathrm{l}$, with the increase in digestion time from 01 to 25 days. The value of percentage BOD reduction varied from 23.05 to $57.25 \%$ while percentage COD reduction varied from $18.63 \%$ to $49.61 \%$. The value of total solids, total dissolved solids and volatile solids ranged between $12.59 \%$ to $37.00 \%, 16.27 \%$ to $41.86 \%$ and $21.87 \%$ to $46.87 \%$ respectively.

At $35^{\circ} \mathrm{C}$ BOD and COD of the treatment, mixture ranged between $1462 \mathrm{mg} / \mathrm{l}$ to $575 \mathrm{mg} / \mathrm{l}$ and $5720 \mathrm{mg} / \mathrm{l}$ to $2318 \mathrm{mg} / \mathrm{l}$ respectively. The total dissolved solids ranged from 254 $\mathrm{mg} / \mathrm{l}$ to $152 \mathrm{mg} / \mathrm{l}$, total dissolved solids ranged from 172 $\mathrm{mg} / \mathrm{l}$ to $98 \mathrm{mg} / \mathrm{l}$ and volatile solids ranged from $128 \mathrm{mg} / \mathrm{l}$ to $62 \mathrm{mg} / \mathrm{l}$, with the increase in digestion time from 01 to 25 days. The value of percentage BOD reduction varied from $19.56 \%$ to $60.67 \%$ while percentage COD reduction varied from $17.74 \%$ to $59.47 \%$. The value of total solids, total dissolved solids and volatile solids ranged between $11.02 \%$ to $40.15 \%, 12.79 \%$ to $43.02 \%$ and $18.75 \%$ to $51.56 \%$ respectively.

At $40^{\circ} \mathrm{C}$ BOD and $\mathrm{COD}$ of the treatment, mixture ranged between $1462 \mathrm{mg} / \mathrm{l}$ to $481 \mathrm{mg} / \mathrm{l}$ and $5720 \mathrm{mg} / \mathrm{l}$ to $1957 \mathrm{mg} / \mathrm{l}$ respectively. The total dissolved solids ranged from 254 $\mathrm{mg} / \mathrm{l}$ to $132 \mathrm{mg} / \mathrm{l}$, total dissolved solids ranged from 172 $\mathrm{mg} / \mathrm{l}$ to $78 \mathrm{mg} / \mathrm{l}$ and volatile solids ranged from $128 \mathrm{mg} / \mathrm{l}$ to $50 \mathrm{mg} / \mathrm{l}$, with the increase in digestion time from 01 to 25 days. The value of percentage BOD reduction varied from $28.45 \%$ to $67.09 \%$ while percentage COD reduction varied from $24.44 \%$ to $65.78 \%$. The value of total solids, total dissolved solids and volatile solids ranged between $15.57 \%$ to $48.03 \%, 20.93 \%$ to $54.65 \%$ and $26.56 \%$ to $60.93 \%$ respectively.

At $45^{\circ} \mathrm{C}$ BOD and $\mathrm{COD}$ of the treatment, mixture ranged between $1462 \mathrm{mg} / \mathrm{l}$ to $538 \mathrm{mg} / \mathrm{l}$ and $5720 \mathrm{mg} / \mathrm{l}$ to $2217 \mathrm{mg} / \mathrm{l}$ respectively. The total dissolved solids ranged from 254 $\mathrm{mg} / \mathrm{l}$ to $140 \mathrm{mg} / \mathrm{l}$, total dissolved solids ranged from 172 $\mathrm{mg} / \mathrm{l}$ to $90 \mathrm{mg} / \mathrm{l}$ and volatile solids ranged from $128 \mathrm{mg} / \mathrm{l}$ to $60 \mathrm{mg} / \mathrm{l}$, with the increase in digestion time from 01 to 25 days. . The value of percentage BOD reduction varied from $24.62 \%$ to $63.20 \%$ while percentage COD reduction varied from $20.69 \%$ to $61.24 \%$. The value of total solids, total dissolved solids and volatile solids ranged between $12.59 \%$ to $44.88 \%, 18.60 \%$ to $47.67 \%$ and $20.31 \%$ to $53.12 \%$ respectively.

Table 2: Percentage Reduction of BOD at $30^{\circ} \mathrm{C}, 35^{\circ} \mathrm{C}, 40^{\circ} \mathrm{C}$ and $45^{\circ} \mathrm{C}$ Temperature

\begin{tabular}{|c|c|c|c|c|c|}
\hline $\begin{array}{c}\text { S. } \\
\text { No. }\end{array}$ & Digestion & \multicolumn{4}{|c|}{$\%$ BOD Reduction } \\
\cline { 3 - 6 } & Time (days) & At $30^{\circ} \mathrm{C}$ & At $35^{\circ} \mathrm{C}$ & At $40^{\circ} \mathrm{C}$ & At $45^{\circ} \mathrm{C}$ \\
\hline 1. & 5 & 23.05 & 19.56 & 28.45 & 24.62 \\
\hline 2. & 10 & 36.73 & 29.13 & 40.56 & 36.38 \\
\hline 3. & 15 & 48.29 & 42.81 & 49.52 & 47.87 \\
\hline 4. & 20 & 54.58 & 49.84 & 60.09 & 57.85 \\
\hline 5. & 25 & 57.25 & 51.50 & 67.78 & 63.20 \\
\hline
\end{tabular}

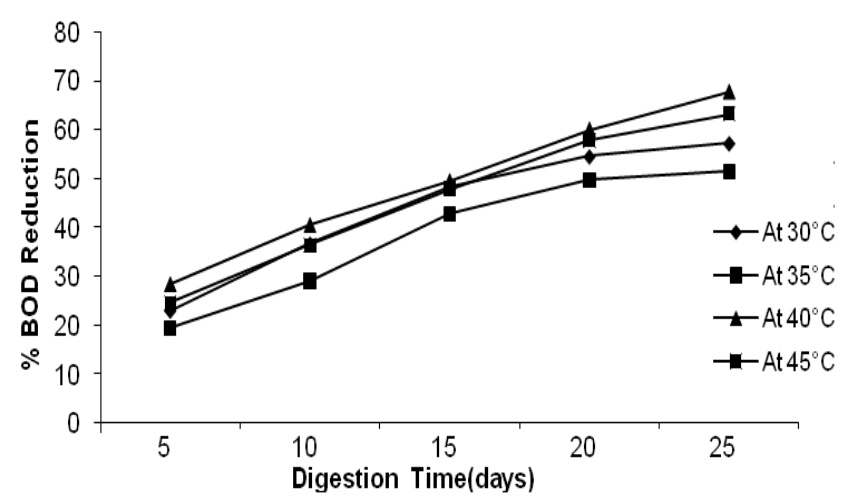

Figure 2: Effect of digestion time on \% BOD Reduction at four different temperatures

Table 3: Percentage Reduction of COD at $30^{\circ} \mathrm{C}, 35^{\circ} \mathrm{C}, 40^{\circ} \mathrm{C}$ and $45^{\circ} \mathrm{C}$ Temperature

\begin{tabular}{|c|c|c|c|c|c|}
\hline S. & Digestion & \multicolumn{3}{|c|}{ \% COD Reduction } \\
\cline { 3 - 6 } No. & Time(days) & At $30^{\circ} \mathrm{C}$ & At $35^{\circ} \mathrm{C}$ & At $40^{\circ} \mathrm{C}$ & At $45^{\circ} \mathrm{C}$ \\
\hline 1. & 5 & 18.63 & 17.74 & 24.44 & 20.69 \\
\hline 2. & 10 & 33.46 & 28.70 & 36.53 & 33.93 \\
\hline 3. & 15 & 42.36 & 40.85 & 46.76 & 42.79 \\
\hline 4. & 20 & 49.33 & 49.84 & 55.85 & 54.09 \\
\hline 5. & 25 & 49.61 & 59.47 & 65.78 & 61.24 \\
\hline
\end{tabular}

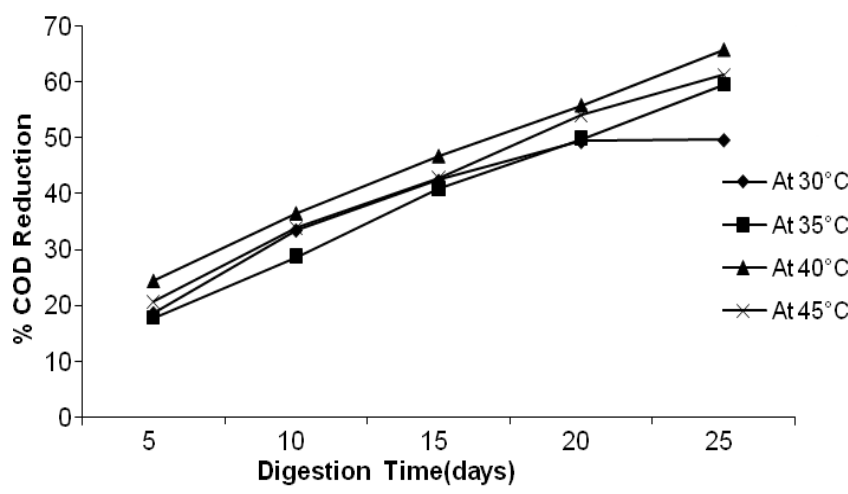

Figure 3: Effect of digestion time on \% COD Reduction at four different temperatures

Table 4: Percentage Reduction of Total Solids at $30^{\circ} \mathrm{C}$, $35^{\circ} \mathrm{C}, 40^{\circ} \mathrm{C}$ and $45^{\circ} \mathrm{C}$ Temperature

\begin{tabular}{|c|c|c|c|c|c|}
\hline S. & Digestion & \multicolumn{4}{|c|}{ \% TS Reduction } \\
\cline { 3 - 6 } No. & Time (days) & At $30^{\circ} \mathrm{C}$ & At $35^{\circ} \mathrm{C}$ & At $40^{\circ} \mathrm{C}$ & At $45^{\circ} \mathrm{C}$ \\
\hline 1. & 5 & 12.59 & 11.02 & 15.74 & 12.59 \\
\hline 2. & 10 & 22.04 & 22.04 & 28.34 & 24.40 \\
\hline 3. & 15 & 30.70 & 29.92 & 36.22 & 34.64 \\
\hline 4. & 20 & 36.22 & 36.22 & 42.51 & 40.15 \\
\hline 5. & 25 & 37.00 & 40.15 & 48.03 & 44.88 \\
\hline
\end{tabular}

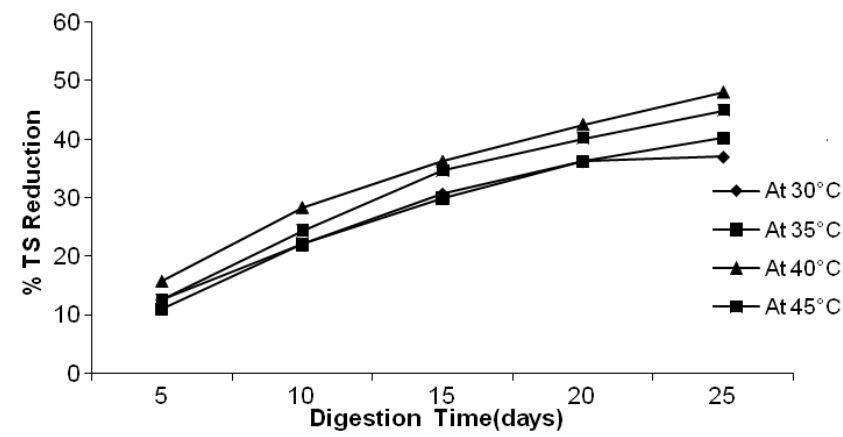

Figure 4: Effect of digestion time on \% TS Reduction at four different temperatures 


\section{International Journal of Science and Research (IJSR) \\ ISSN (Online): 2319-7064 \\ Index Copernicus Value (2013): 6.14 | Impact Factor (2014): 5.611}

Table 5: Percentage Reduction of Total Dissolved Solids at $30^{\circ} \mathrm{C}, 35^{\circ} \mathrm{C}, 40^{\circ} \mathrm{C}$ and $45^{\circ} \mathrm{C}$ Temperature

\begin{tabular}{|c|c|c|c|c|c|}
\hline S. No. & Digestion & \multicolumn{4}{|c|}{$\%$ TDS Reduction } \\
\cline { 3 - 6 } & Time(days) & At $30^{\circ} \mathrm{C}$ & At $35^{\circ} \mathrm{C}$ & At $40^{\circ} \mathrm{C}$ & At $45^{\circ} \mathrm{C}$ \\
\hline 1. & 5 & 16.27 & 12.79 & 20.93 & 18.60 \\
\hline 2. & 10 & 25.58 & 22.09 & 31.39 & 26.74 \\
\hline 3. & 15 & 32.55 & 31.39 & 43.02 & 38.37 \\
\hline 4. & 20 & 40.69 & 38.37 & 50.00 & 44.18 \\
\hline 5. & 25 & 41.86 & 43.02 & 54.65 & 47.67 \\
\hline
\end{tabular}

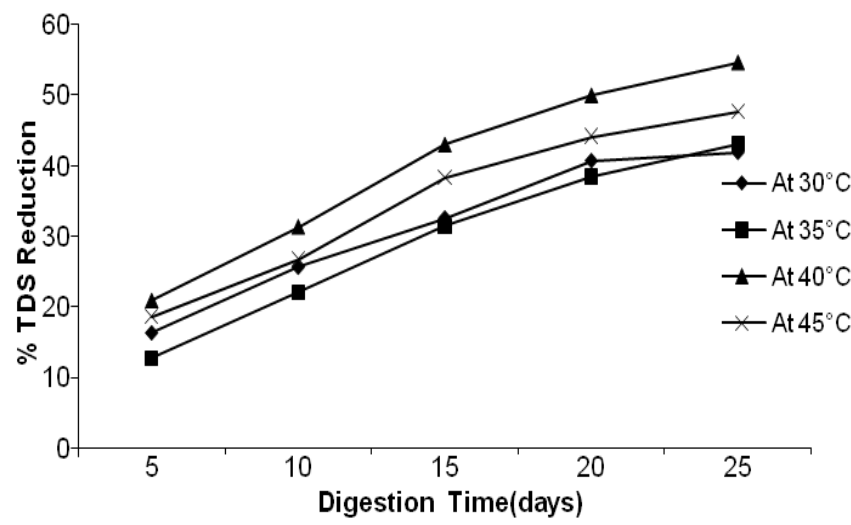

Figure 5: Effect of digestion time on \% TDS Reduction at four different temperatures

Table 6: Percentage Reduction of Volatile Solids at $30^{\circ} \mathrm{C}$, $35^{\circ} \mathrm{C}, 40^{\circ} \mathrm{C}$ and $45^{\circ} \mathrm{C}$ Temperature

\begin{tabular}{|c|c|c|c|c|c|}
\hline S. No. & Digestion & \multicolumn{4}{|c|}{ \% VS Reduction } \\
\cline { 3 - 6 } & Time(days) & At $30^{\circ} \mathrm{C}$ & At $35^{\circ} \mathrm{C}$ & At $40^{\circ} \mathrm{C}$ & At $45^{\circ} \mathrm{C}$ \\
\hline 1. & 5 & 21.87 & 18.75 & 26.56 & 20.31 \\
\hline 2. & 10 & 29.68 & 29.68 & 35.93 & 32.81 \\
\hline 3. & 15 & 35.93 & 43.75 & 46.87 & 42.18 \\
\hline 4. & 20 & 43.75 & 48.43 & 56.25 & 51.56 \\
\hline 5. & 25 & 46.87 & 51.56 & 60.93 & 53.12 \\
\hline
\end{tabular}

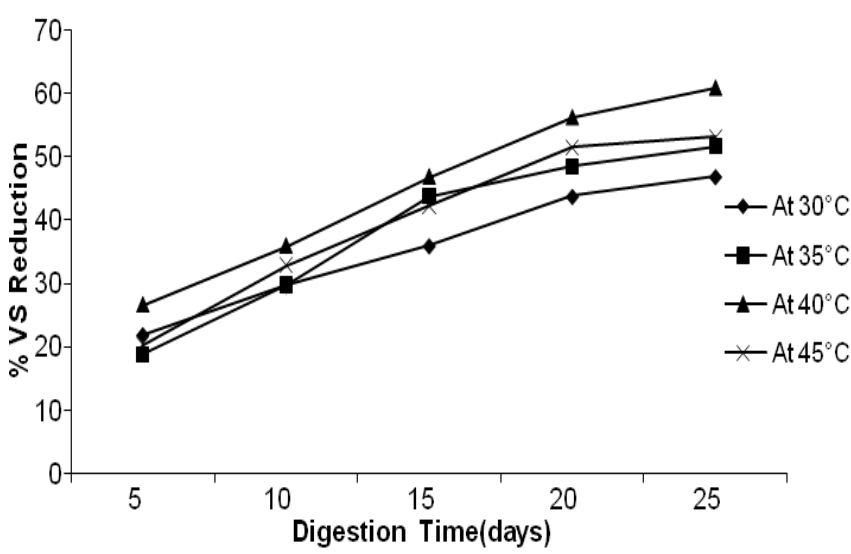

Figure 6: Effect of digestion time on \% VS Reduction at four different temperatures

\section{Results}

Results indicate that there was a steady increase in the percentage reduction of BOD, COD, TS, TDS and VS from $5^{\text {th }}$ to $20^{\text {th }}$ day, but the rate of percentage reduction decreased after a $20^{\text {th }}$ day at all the four different temperatures. Cumulative biogas production and rate of biogas production during the digestion process was also measured. The results indicate that there was a steady increase in the yield of biogas from $7^{\text {th }}$ day onwards and it attained a peak value on $20^{\text {th }}$ treatment then after it started decreasing. The decrease in the biogas production was because of a decrease in organic matter in digestion mixture. The biogas production and reduction in effluent characteristics at various temperatures observed can be depicted as-

\section{Reduction at $40^{\circ} \mathrm{C}>$ Reduction at $45^{\circ} \mathrm{C}>$ Reduction at $35^{\circ} \mathrm{C}>$ Reduction at $30^{\circ} \mathrm{C}$}

It showed that optimum temperature for reduction in effluent characteristics and biogas production was at $40^{\circ} \mathrm{C}$. The average composition of the biogas at the end of digestion at $40^{\circ} \mathrm{C}$ was: $\mathrm{CH}_{4}$ content varied from $63.0-63.8 \%, \mathrm{CO}_{2}$ varied from $32-33 \%, \mathrm{O}_{2}$ varied from $0.5-0.7 \%$ and $\mathrm{CO}$ varied from $0.3-0.7 \%$.

\section{Conclusion}

This work studied the anaerobic degradation of phenolic wastewater at four different temperatures $30^{\circ} \mathrm{C}, 35^{\circ} \mathrm{C}, 40^{\circ} \mathrm{C}$ and $45^{\circ} \mathrm{C}$. Degradation of phenol, chemical oxygen demand (COD), biochemical oxygen demand (BOD), total solids (TS), total dissolved solids (TDS), volatile solids (VS)and biogas were evaluated. Phenol is not degradable under acidogenic conditions by acidogenic bacteria. There was a steady increase in the percentage reduction of BOD, COD, TS, TDS and VS from $5^{\text {th }}$ to $20^{\text {th }}$ day, but the rate of percentage reduction decreased after the $20^{\text {th }}$ day. There was a steady increase in the yield of biogas from $7^{\text {th }}$ day onwards and it attained a peak value on $20^{\text {th }}$ treatment then after it started decreasing.

\section{References}

[1] Chang, Y. J., Nishio, N., and Nagai, S. (1995), "Characteristics of granular methanogenic sludge grown on phenol synthetic medium and methanogenic fermentation of phenolic wastewater in a UASB reactor." J. Ferment. Bioeng. 79 (4), 348-353.

[2] Colleran, E., Pender, S., (2002), “ Mesophilic and thermophilic anaerobic digestion of sulphate-containing wastewaters. Water Sci. Technol. 45, 231-235.

[3] Collins, G., Foy, C., McHugh, S., O’Flaherty, V.(2005), "Anaerobic treatment of 2,4,6-trichlorophenol in an expanded granular sludge bed anaerobic filter (EGSBAF)

[4] Fang, H. H. P., Chen, T., Li, Y. Y., and Chui, H. K. (1996), "Degradation of phenol in wastewater in an upflow anaerobic sludge blanket reactor." Water Res. 30 (6), 1353-1360.

[5] G. Collins., Water Research 39 (2005) 1614-1620 1619 bioreactor at $151 \mathrm{C}$. FEMS Microbiology Ecology in press (Online 21st November 2004).

[6] Guieysse, B., Wickstro“ m, P., Forsman, M., Mattiasson, B., (2001), “.Biomonitoring of continuous microbial community adaptation towards more efficient phenol degradation in fed-batch reactor". Appl. Microbiol. Biotechnol. 56, 780-787.

[7] Hwang, P. C., and Cheng, S. S. (1991). "The influence of glucose supplement on the degradation of catechol." Water Sci. Technol. 23, 1201-1209.

[8] Hernandez., J.E. (2003)," Removal of polyphenols contained in wastewater using anaerobic digestion." Sheffield, The University of Sheffield.

\section{Volume 4 Issue 11, November 2015}




\section{International Journal of Science and Research (IJSR) \\ ISSN (Online): 2319-7064}

Index Copernicus Value (2013): 6.14 | Impact Factor (2014): 5.611

[9] Kennes, C., Mendez, R., and Lema, J. M. (1997), "Methanogenic degradation of p-cresol in batch and in continuous UASB reactors." Water Res. 31(7), 15491554.

[10]Lettinga, G., Rebac, S., Zeeman, G., (2001), Challenge of psychrophilic anaerobic wastewater treatment." Trends Biotechnol. 19, 363-370.

[11] McHugh, S., Carton, M.W., Collins, O'Flaherty, V., (2004), " Reactor performance and microbial community dynamics during anaerobic biological treatment of wastewaters at $16-37{ }^{0} \mathrm{C}$ ". FEMS Microbiol. Ecol. 48, 369-378.

[12]Li, Y.Y., Fang, H.H.P., Chui, H.K., Chen, T.(1996), “ UASB treatment of wastewater with concentrated benzoate. "J. Environ. Eng. ASCE. 12, 401-411.

[13] Rebecca, S., Gerbens, S., Lens, P.N., van Lier, J.B., Stams, A.J.M., Keesman, K.J., Lettinga, G., (1999), “ Kinetics of fatty acid degradation by psychrophilically grown anaerobic granular sludge." Bioresource Technol. 69, 241-248.

[14] Tay, J. H., He, Y. X., and Yan, Y. G. (2000), "Anaerobic biogranulation using phenol as the sole carbon source." Water Environ. Res. 72, 189-194.

[15] Tay, J. H., He, Y. X., and Yan, Y. G. (2001), “Improved anaerobic degradation of phenol with supplemental glucose." J. Environ. Eng. 127(1), 38-45.

[16] Veeresh, G. S. (2004), "Phenolic wastewater: BMP and treatment using UASB reactor." Ph.D. thesis, Indian Institute of Technology Roorkee, Roorkee, India.

[17] Veeresh, G. S., Kumar, P., and Mehrotra, I. (2005), "Treatment of phenol and cresols in upflow anaerobic sludge blanket (UASB) process: A review." Water Res. 39(1), 154-170. 